\title{
Recent Advances in AIEgens for Metal Ion Biosensing and Bioimaging
}

\author{
Yongming $\mathrm{Li}^{1,2}$, Huifei Zhong ${ }^{1,2}$, Yanyan Huang ${ }^{1,2, *}$ and Rui Zhao ${ }^{1,2}$ \\ 1 Beijing National Laboratory for Molecular Sciences, \\ CAS Key Laboratory of Analytical Chemistry for Living Biosystems, \\ CAS Research/Education Center for Excellence in Molecular Sciences, Institute of Chemistry, \\ Chinese Academy of Sciences, Beijing 100190, China; liyongming@iccas.ac.cn (Y.L.); \\ zhonghuifei@iccas.ac.cn (H.Z.); zhaorui@iccas.ac.cn (R.Z.) \\ 2 University of Chinese Academy of Sciences, Beijing 100049, China \\ * Correspondence: yyhuang@iccas.ac.cn; Tel.: +86-10-6255-7910 \\ Academic Editor: F. Christopher Pigge \\ Received: 15 November 2019; Accepted: 11 December 2019; Published: 16 December 2019
}

\begin{abstract}
Metal ions play important roles in biological system. Approaches capable of selective and sensitive detection of metal ions in living biosystems provide in situ information and have attracted remarkable research attentions. Among these, fluorescence probes with aggregation-induced emission (AIE) behavior offer unique properties. A variety of AIE fluorogens (AIEgens) have been developed in the past decades for tracing metal ions. This review highlights recent advances (since 2015) in AIE-based sensors for detecting metal ions in biological systems. Major concerns will be devoted to the design principles, sensing performance, and bioimaging applications.
\end{abstract}

Keywords: metal ions; aggregation-induced emission; biosensing; bioimaging

\section{Introduction}

Metal ions play crucial roles in various biological processes and are required by all life forms. The diverse functions of metal ions include osmotic maintenance, signal transduction, catalysis, and proliferation [1]. In addition to functionality, the biodistribution, dynamic ranges, and existing forms of metal ions are also highly varied. Alkali and alkaline earth metal ions are of millimolar level and ubiquitous in every organ. Transition metal ions are usually with lower abundance [2,3]. Owing to their versatile coordination ability, many transition metal ions act as co-factors of macro biomolecules, such as $\mathrm{Fe}^{2+}$ in hemoglobin, $\mathrm{Zn}^{2+}$ in zinc finger, and $\mathrm{Mn}^{2+}$ in photosystems [4,5]. Despite growing knowledge about metal ions, the distribution, metabolism, and mechanism of actions of many metals are largely uncharacterized [1]. The abnormal homeostasis of metal ions has been revealed to be related to diseases including cancer, neurodegenerative disease, and diabetes [6,7]. The exposure and accumulation of toxic metal ions also bring great threat to human health [8-10]. However, their exact roles in disease pathologies still largely remain unclear [7]. To address these, sensing systems capable of identification, quantification, and monitoring of metal ions in living biosystems are urgently demanded.

Fluorescent sensors with high sensitivity, simplicity, and visualization have attracted considerable research interests for analyzing biological events in vitro and in vivo. In the past several decades, fluorescent sensors became powerful tools for investigating metal ions in complicated systems. Different recognition moieties and sensing mechanisms were developed to introduce high specificity and sensitivity [11-15]. As an intrinsic property of metal ions, coordination lays an important foundation for metal ion recognition. Reaction-based mechanism is also adopted for selectively sensing respective ions $[16,17]$. However, conventional fluorescent dyes still suffer from problems including 
severe background interference, aggregation-induced quenching (ACQ) effect, and poor photostability, which hinder detection sensitivity, real-time and long-term monitoring of biosystems [18,19].

Aggregation-induced emission fluorogens (AIEgens) first reported by Prof. Tang's group in 2001 possess unique advantages of activatable emission, good photostability, and compatibility with high concentration thus high sensitivity [20]. These fluorophores are non-emissive or weakly emissive in diluted solution but strongly emissive upon aggregation resulted from the restriction of intramolecular motion (RIM) [21], providing large Stokes' shift, strong light tolerance and high signal-to-noise ratio [22-25]. A number of molecules have been reported with AIE behavior, including tetraphenylethene (TPE), hexaphenylsilole (HPS), and quinoline-malononitrile (QM) [19,22,23] (Figure 1). Their tailorable structures allow further modification of the AIEgens with functional molecules and materials, such as nucleic acids, peptides, graphene, and metal-organic frameworks (MOFs) [26-29]. The successful applications have been demonstrated in the fields of detection, disease diagnosis, and therapy [30-34]. In terms of metal ion analysis, different AIE-based sensing systems have been developed which accelerate the understanding the roles of these ions in biological samples. The sensing mechanism is crucial for the analytical performance of the sensors. These systems usually contain two parts: recognition moiety and signaling moiety. AIE cores play the role of signal output, while modifications on AIE structures enable the selective recognition. Coordination chemistry and metal-related reactions are two major approaches for the recognition. The presence of target ion changes the signal output of AIE cores, which enables sensitive detection.
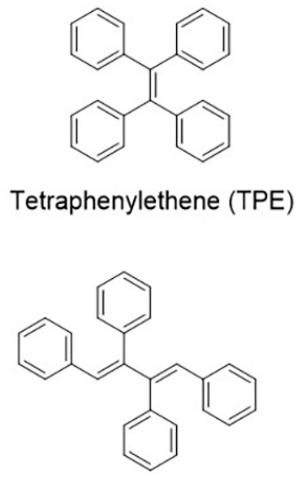

Tetraphenyl-1,4-butadiene (TPBD)

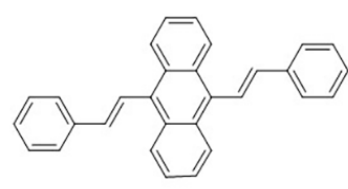

Distyreneanthracene (DSA)

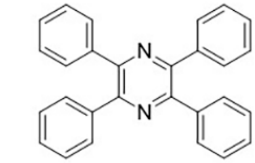

Tetraphenylpyrazine (TPP)

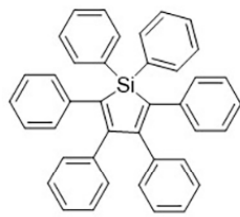

Hexaphenylsilole (HPS)

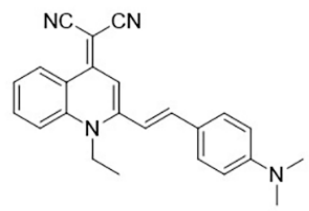

Quinoline-malononitrile (QM)

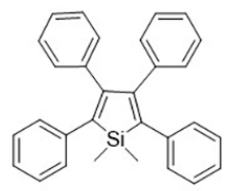

1,1-dimethyl-2,3,4,5-tetraphenylsilole (DMTPS)

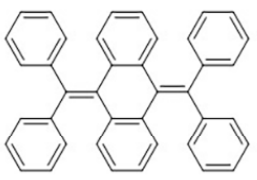

9,10-bis(diphenylmethylene)-9,10-dihydroanthracene (PDHA)

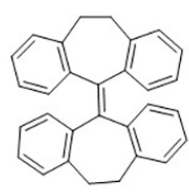

$10,10^{\prime}, 11,11$ '-tetrahydro-5,5'-bidibenzo[a,d][7]annulenylidene (THBA)

Figure 1. Structure of some common aggregation-induced emission fluorogens (AIEgens).

Given the importance of metal ions and the continuously growing body of AIEgens for metal ion detection, this review focuses on recent development of AIE-based sensors for detecting and imaging of metal ions in biological systems. Major concerns will be devoted to the design principles, sensing performance, and applications for tracing metal ions in vitro and in vivo.

\section{Alkali Metal Ions}

Alkali metals include lithium $(\mathrm{Li})$, sodium $(\mathrm{Na})$, potassium $(\mathrm{K})$, rubidium $(\mathrm{Rb})$, cesium $(\mathrm{Cs})$, and francium (Fr). The concentration of $\mathrm{Na}^{+}$and $\mathrm{K}^{+}$in human body is of millimolar level and differs widely between intracellular and extracellular region [3]. Crown ether, aza-crown ether, and their 
derivates are the traditional recognition components for these ions due to the selection of cavity. The sensing and detection of alkali metal ions are mainly focus on $\mathrm{Li}^{+}, \mathrm{Na}^{+}$, and $\mathrm{K}^{+}$. There has been an excellent review on fluorescent probes for alkali metals and alkaline earth metals [35].

For conventional AIEgens, water solubility is usually a problem which prevents their applications for biosensing and bioimaging. The introduction of biomolecules can overcome this issue. Tan et al. modified TPE derivative with G-rich DNA oligonucleotide for the detection and imaging of $\mathrm{K}^{+}$[36]. The oligonucleotide moiety not only enhanced water solubility, but also provided biocompatibility and cell permeability. This probe was weakly emissive in aqueous solution. In the presence of $\mathrm{K}^{+}$, parallel G-Quadruplex structure could be induced, which gathered TPE groups. The $\pi-\pi$ stacking interactions among phenyl-ring motifs of TPE derivatives further stabilized the G-Quadruplex structure. Thereby, fluorescent emission was significantly enhanced. This turn-on probe showed a detection limit of $5 \mu \mathrm{M}$ towards $\mathrm{K}^{+}$in Tris- $\mathrm{HCl}$ buffer. The feasibility of the probe for sensing $\mathrm{K}^{+}$in living cells was also demonstrated. Strong fluorescence was emitted from cytoplasm of HeLa cells after treated with the probe. The disappearance of the blue emission after the treatment $\mathrm{K}^{+}$suppressing reagents confirmed the feasibility and reversibility of this probe for detection and imaging of $\mathrm{K}^{+}$.

\section{Alkaline Earth Metal Ions}

Alkaline earth metals are in group 2 of the periodic table, including beryllium (Be), magnesium $(\mathrm{Mg})$, calcium (Ca), strontium ( $\mathrm{Sr}$ ), barium (Ba), and radium ( $\mathrm{Ra})$. Among these metals, $\mathrm{Mg}$ and $\mathrm{Ca}$ are involved in many biological processes, such as signal transduction and regulation of enzyme activity. The normal concentrations of $\mathrm{Mg}^{2+}$ and $\mathrm{Ca}^{2+}$ are usually in the ranges of $0.5-20 \mathrm{mM}$ and $0.1 \mu \mathrm{M}-2 \mathrm{mM}$, respectively [3]. The abnormality in their concentrations may cause a series of diseases, such as hypertension, osteoporosis, neuronal injury, soft tissue calcification, and hypercalcemia [37-39]. Probes containing $\beta$-ketoester, $\beta$-carboxyester, benzylguanine, or carboxyl moiety are usually designed to detect and sense $\mathrm{Mg}^{2+}$ and $\mathrm{Ca}^{2+}[35]$.

For AIEgens, carboxyl or nitrogenous groups are usually integrated into the structures for $\mathrm{Mg}^{2+}$ and $\mathrm{Ca}^{2+}$ binding. Chemoensors including small molecules and polymers based on AIE phenomenon have been developed [40-42]. An AIE probe synthesized by the condensation reaction between benzene-1, 2-diamine and 5-bromo-2-hydroxybenzaldehyde was reported for $\mathrm{Mg}^{2+}$ detection [40]. A group of polymer sensors based on TPE appended poly(acrylic acid) derivatives [PAA-TPE $(x=0.01-0.05)]$ were reported for detecting $\mathrm{Ca}^{2+}[41,42]$. The binding towards $\mathrm{Ca}^{2+}$ was realized via

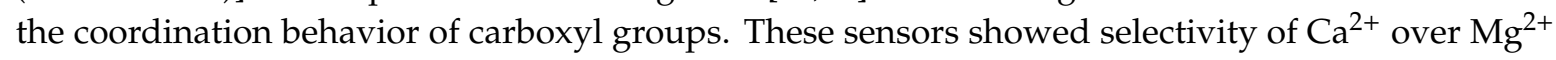
due to the more effective induction of chain folding.

Water solubility, high selectivity and appropriate responding range are important for analyzing $\mathrm{Mg}^{2+}$ and $\mathrm{Ca}^{2+}$ in living systems. An AIE-active $\mathrm{Ca}^{2+}$ probe $\left(\mathrm{SA}-4 \mathrm{CO}_{2} \mathrm{Na}\right)$ was developed with a millimolar responding range which fitted the requirement for $\mathrm{Ca}^{2+}$ analysis in biosystems [43]. Two iminodiacetate groups with negative charge were modified to SA fluorogen acting as recognition groups (Figure 2a). In the presence of $\mathrm{Ca}^{2+}$, the chelation between two iminodiacetate groups and one metal ion gave fibrillar aggregates with strong fluorescence enhancement at $541 \mathrm{~nm}$ (Figure 2b). The linear range of $0.6-3.0 \mathrm{mM}$ was suitable to discriminate normal (1.0-1.4 $\mathrm{mM})$ and hypercalcemic (1.4-3.0 mM) $\mathrm{Ca}^{2+}$ concentration. SA- $4 \mathrm{CO}_{2} \mathrm{Na}$ was successfully applied to imaging $\mathrm{Ca}^{2+}$ in different biological samples, including human psammomatous meningioma slice with calcium deposits and bovine bone microcracks (Figure $2 \mathrm{c}, \mathrm{d}$ ). Compared with commercial dyes calcein, SA-4CO $\mathrm{Na}_{2}$ could image $\mathrm{Ca}^{2+}$ with high signal-to-noise ratio without washing. Selective imaging of $\mathrm{Ca}^{2+}$ with clear background demonstrated great potential of this probe for broad biomedical applications. 
(a)

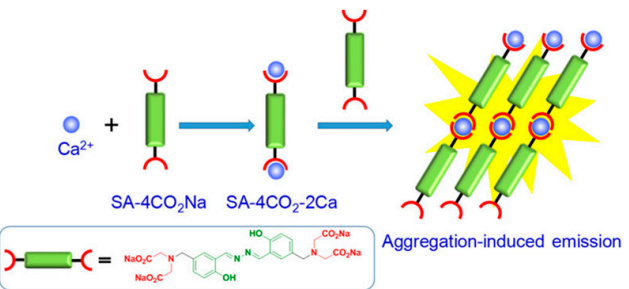

(b)

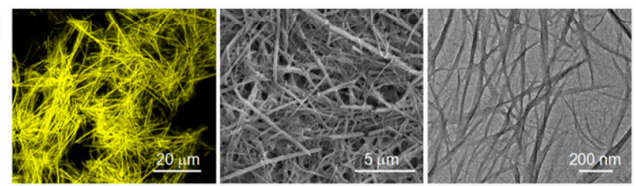

(c)

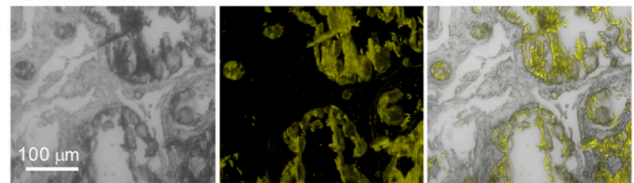

(d)
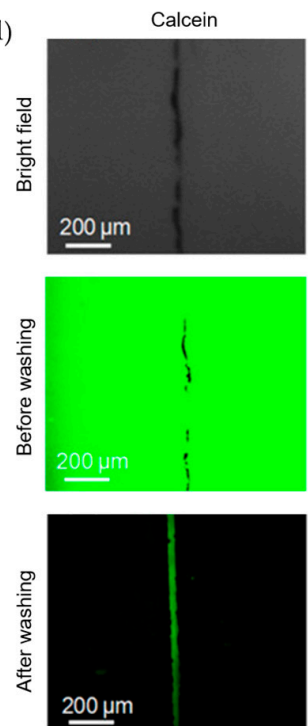

$\mathrm{SA}-\mathrm{CO}_{2} \mathrm{Na}$
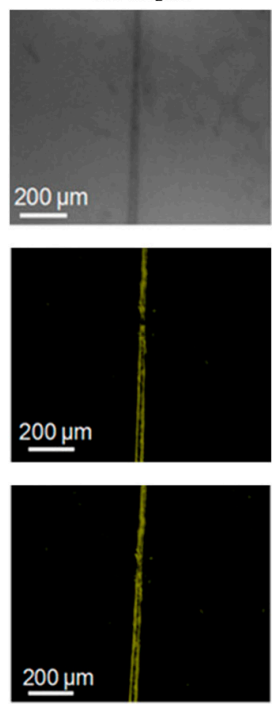

Figure 2. (a) $\mathrm{Ca}^{2+}$ sensing mechanism of the turn-on probe $\mathrm{SA}-4 \mathrm{CO}_{2} \mathrm{Na}$ [43] (Reproduced with permission from [43]). (b) Fluorescence, SEM, and TEM images of SA-4 $\mathrm{CO}_{2} \mathrm{Na}$ upon $\mathrm{Ca}^{2+}$ addition. (c) Fluorescence images of calcium deposits in psammomatous meningioma slice. (d) Fluorescence images of bovine bone microcracks by treated with calcein and $\mathrm{SA}-4 \mathrm{CO}_{2} \mathrm{Na}$.

With water solubility and coordinating ability towards $\mathrm{Ca}^{2+}$, bidentate pyridine carboxylate was anchored on TPE for the design of $\mathrm{Ca}^{2+}$ sensor [44]. Upon $\mathrm{Ca}^{2+}$ recognition, coordination oligomers or polymers formed with decreased solubility. The aggregation enhanced fluorescence emission which released detectable signal. The sensor was applied for imaging $\mathrm{Ca}^{2+}$ in A549 cells. The appearance of blue fluorescence in cytoplasmic area suggested the binding of $\mathrm{Ca}^{2+}$. AIEgens are also involved in the structures of polymers for the development of ion sensors. Liu et al. synthesized a copolymer PEN-TPE/PPL (PEN: polyarylene ether nitrile; TPE: tetraphenylethene; PPL: phenolphthalin) through the copolymerization of TPE-2OH, 2, 6-dichlorobenzonitile (DCBN) and phenolphthalein (PPL) (Figure 3a) [45]. With the presence of carboxyl group, PEN-TPE/PPL showed coordination towards metal ions, including $\mathrm{Cu}^{2+}, \mathrm{Pb}^{2+}, \mathrm{Zn}^{2+}$, and $\mathrm{Ca}^{2+}$. Among these, $\mathrm{Ca}^{2+}$ caused the largest emission enhancement. Mechanism investigation indicated that $\mathrm{Ca}^{2+}$ induced crosslinking of PEN-TPE/PPL and the formation of nanospheres. These nanospheres could penetrate EMT-6 cells and concentrate in cytoplasm.

a)

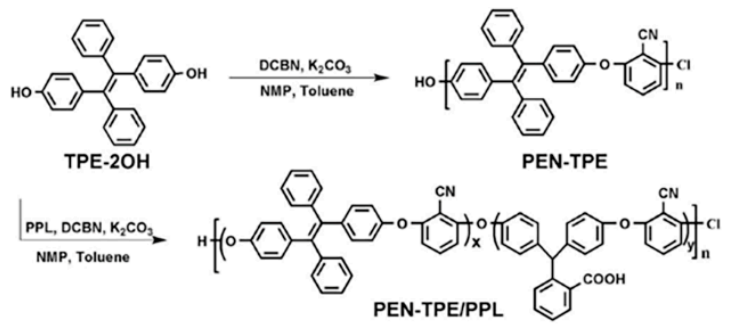

b)

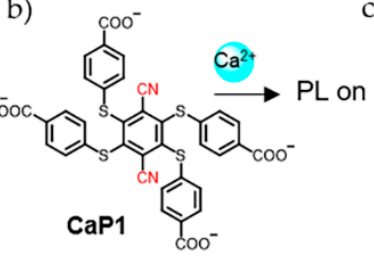

c)

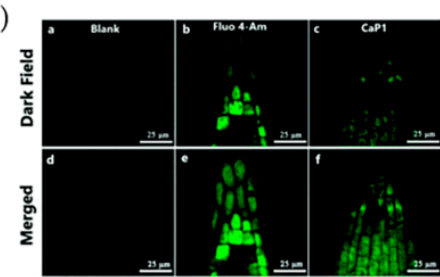

Figure 3. (a) Synthesis of a copolymer PEN-TPE/PPL for the detection of $\mathrm{Ca}^{2+}[45]$. (b,c) A molecular probe (CaP1) with $\mathrm{Ca}^{2+}$-responsive signal for analyzing $\mathrm{Ca}^{2+}$ in the root cells of Arabidopsis thaliana [46] (Reproduced with permission from $[45,46])$. 
Aggregation-induced phosphorescence (AIP) property was also introduced for the detection of $\mathrm{Ca}^{2+}$. Recently, a molecular probe (CaP1) with phosphorescent properties was developed [46]. In the presence of $\mathrm{Ca}^{2+}$, each CaP1 molecule coordinated two $\mathrm{Ca}^{2+}$ ions via cyano and carboxyl groups to form linear long chains (Figure 3b). Precipitated particles were produced with AIP characteristics. Due to the long lifetime of phosphorescence, time-gated detection method was established which effectively inhibited autofluorescence. CaP1 was observed to successfully enter cells and emit phosphorescence responding to $\mathrm{Ca}^{2+}$ in the root cells of Arabidopsis thaliana, which could be a useful tool for studying the biological roles of $\mathrm{Ca}^{2+}$ in plants (Figure $3 \mathrm{c}$ ).

\section{Transition Metal Ions}

Transition metals include a large family of metal elements. These metals vary in chemical properties, concentration, distribution, and acting roles in living biosystems. Most transition metal ions show good coordination ability, which is one main point to design binding group. Metal-mediated reactions are also useful to selectively recognize metal ions $[16,17,47,48]$. In this part, several common transition metal ions sensed by AIE probes are discussed, including Mercury, $\mathrm{Fe}^{3+}, \mathrm{Cu}^{2+}, \mathrm{Zn}^{2+}, \mathrm{Ag}^{+}$, $\mathrm{Ni}^{2+}, \mathrm{Cr}^{3+}$, and $\mathrm{Au}^{3+}$.

\subsection{Mercury Ions}

Mercury is toxic and a great threat to human health. The bioaccumulation of mercury can cause severe damage to many organs, such as central nervous system, lung, and kidneys [49,50]. Different mechanisms have been investigated for specific sensing of mercury based on AIE phenomenon.

Coordination chemistry has been employed for the recognition of $\mathrm{Hg}^{2+}$ [51-60]. Structures containing Schiff base, sulfydryl, and imidazole groups show effectiveness for $\mathrm{Hg}^{2+}$ binding. Huo et al. synthesized two probes by decorating diaminomaleonitrile moiety on TPE [51]. These probes formed nanoscale aggregates and were emissive in solution with high water fraction $\left(f_{\mathrm{w}}\right)$. In the presence of $\mathrm{Hg}^{2+}$, the $\mathrm{N}$ atoms in diaminomaleonitrile moiety bound $\mathrm{Hg}^{2+}$, which disturbed internal charge transfer and caused fluorescence quenching. This turn-off response was applied for detecting $\mathrm{Hg}^{2+}$ in living cells. Considering the complexity of living systems, turn-on probes can provide accurate information. By incorporating Schiff base unit, Yang et al. designed and synthesized a series of $\alpha$-cyanostilbene derivatives for $\mathrm{Hg}^{2+}$ detection [52-54]. $\mathrm{Hg}^{2+}$ binding drove $\pi-\pi$ stacking and hydrogen bonding between adjacent probes, which hampered the intramolecular rotation thus caused fluorescence enhancement. With improved emission performance, two of these probes were used for imaging $\mathrm{Hg}^{2+}$ in living cells. Recently, a ratiometric probe using an AIEgen has been used for the imaging of $\mathrm{Hg}^{2+}$ in onion inner and outer epidermal tissues [61].

In addition to detection, tracing biological distribution of $\mathrm{Hg}^{2+}$ is important for studying its toxicology. A peptide-based probe was designed by using a tripeptide as $\mathrm{Hg}^{2+}$-targeting moiety and TPE as the signaling group [55]. The incorporation of the peptide not only allowed the highly specific turn-on discrimination of $\mathrm{Hg}^{2+}$ from 19 different metal ions, but also provided high compatibility with physiological environment. For mechanism investigation, peptide analogues were also conjugated with TPE, which suggested the thiol and carboxyl side chains played important roles for the binding with $\mathrm{Hg}^{2+}$ (Figure 4a). Further applications of the sensor for monitoring $\mathrm{Hg}^{2+}$ in living cells and zebrafish were demonstrated. The observation that $\mathrm{Hg}^{2+}$ showed high tendency to accumulate in cell nucleus indicated the damage effect of this ion to this subcellular compartment (Figure $4 \mathrm{~b}$ ). As indicated by the signal of the sensor, the distribution of $\mathrm{Hg}^{2+}$ in chorion of zebrafish embryo and the brain of larvae was related to the deleterious effect of inorganic mercury in living biosystems (Figure 4c). 
(a)

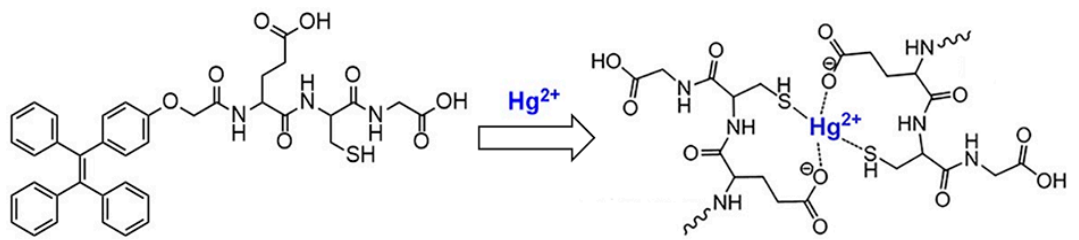

(b)
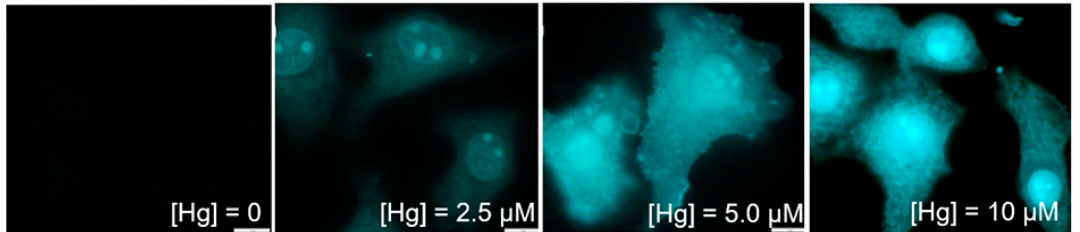

c)

Fluorescence channel

Bright field

Fluorescence channel

Bright field
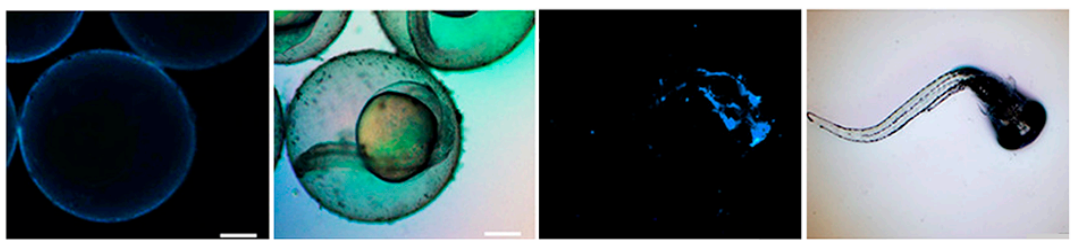

Figure 4. Bind mechanism and sensing performance of peptide-based probe for $\mathrm{Hg}^{2+}$ [55] (Reproduced with permission from [55]). (a) Structure of the probe and binding mechanism to $\mathrm{Hg}^{2+}$. (b) Fluorescence imaging in HeLa cells after incubation with probe and different concentrations of $\mathrm{Hg}^{2+}$. (c) Fluorescence imaging in zebrafish embryo and zebrafish larvae after treated with $\mathrm{Hg}^{2+}$ and probe.

The bioaccumulation of $\mathrm{Hg}^{2+}$ leads to the formation to highly toxic organomercury compounds such as methylmercury $\left(\mathrm{MeHg}^{+}\right)$and phenylmercury $\left(\mathrm{PhHg}^{+}\right)$. Therefore, detection of both inorganic and organic species is crucial to protect ecosystem and human health. Recently, Kong et al. modified four methylated benzimidazole groups on the TPE skeleton to prepare a water soluble AIE probe Tmbipe (Figure 5a) [56]. In addition to $\mathrm{Hg}^{2+}$, benzimidazole groups in Tmbipe could also bind $\mathrm{MeHg}^{+}$ and $\mathrm{PhHg}^{+}$, producing $\mathrm{Hg}^{2+}$-tetracarbene complex via $\mathrm{C}-\mathrm{Hg}$ bonds. The formation of chelate ring restricted the intramolecular rotation and increased molecular planarity, which induced the formation of aggregates and further restricted the molecule skeletal vibration. Due to the unusual coordination mode of $\mathrm{C}-\mathrm{Hg}$, this probe showed high selectivity towards $\mathrm{Hg}^{2+}$ and organomercury. The detection limits for $\mathrm{Hg}^{2+}, \mathrm{MeHg}^{+}$, and $\mathrm{PhHg}^{+}$were estimated as $63 \mathrm{nM}, 94 \mathrm{nM}$, and $78 \mathrm{nM}$, respectively. With good solubility, Tmbipe was successfully applied for imaging $\mathrm{Hg}^{2+}$ in different cells. In another work, a dual detection strategy for the bioaccumulation of $\mathrm{Hg}^{2+}$ in P. phosphoreum was developed by using an AIE sensor 2-AFN-I (Figure 5b) [57]. $\mathrm{Hg}^{2+}$ quenched the strong bioluminescence of P. phosphoreum by interrupting quorum sensing system, meanwhile increased the emission of 2-AFN-I inside the bacteria. This strategy provided a useful inspiration for the imaging and evaluation of bioaccumulated toxins in P. phosphoreum.

In addition to coordination chemistry strategy, reaction-based mechanism is another effective way to sense $\mathrm{Hg}^{2+}[62,63]$. Joshi et al. designed a TPE-monoboronic acid probe to sense and image $\mathrm{Hg}^{2+}$ and $\mathrm{CH}_{3} \mathrm{Hg}^{+}$based on mercury ion-promoted transmetalation reaction (Figure 5c) [64]. After reaction, the transformation of the C-B bond in the probe to $\mathrm{C}-\mathrm{Hg}$ gave poorly soluble TPE- $\mathrm{HgCl}$ or $\mathrm{TPE}-\mathrm{HgMe}$ product. The resultant aggregates, restriction of intramolecular rotation caused fluorescence enhancement. This probe was used to image methylmercury in HEK cells and zebrafish. For $\mathrm{CH}_{3} \mathrm{HgCl}$ pretreated samples, strong blue emission was observed in cells and the whole body of zebrafish. In other examples, $\mathrm{Hg}^{2+}$-induced umpolung reaction was reported to sensing $\mathrm{Hg}^{2+}[65,66]$. 2-mercaptoethanol was integrated with the AIEgen to increase solubility and provide dethioacetalization site. In the presence of $\mathrm{Hg}^{2+}$, mercaptoethanol was substituted by an aldehyde group, leading to AIE phenomenon. Further applications in the detection of $\mathrm{Hg}^{2+}$ in river water, urine samples, living cells, and zebrafish were achieved. 
(a)

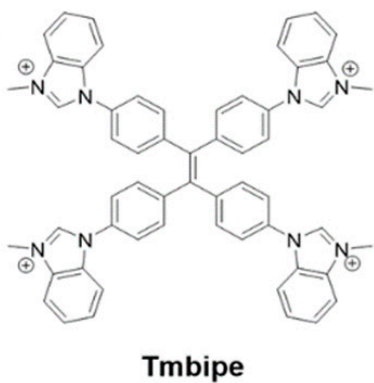

(b)

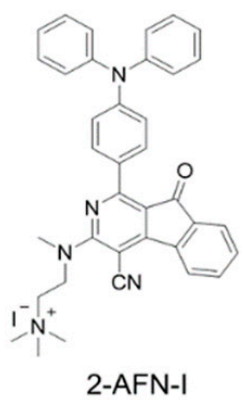

(c)

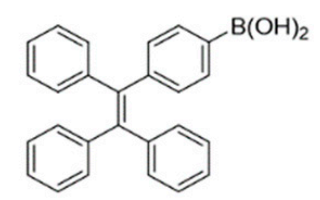

TPE-monoboronic acid probe

Figure 5. Molecular structures of chemosensors for mercury ions. (a) Tmbipe [56]. (b) 2-AFN-I [57].

(c) A TPE-monoboronic acid probe [64] (Reproduced with permission from $[56,57,64]$ ).

Considering the co-existence of multiple species in complicated biosamples, multi-targeting sensors were developed with AIE behaviors. Some dual-responsive strategies have been reported to sense $\mathrm{Hg}^{2+}$ and other targets $[67,68]$. By combining AIE organic nanoparticles with Au nanoparticles, Ouyang et al. developed a dual-emission fluorescent sensor to detect mercury and melamine [68]. The composite exhibited maximum emission wavelengths at $525 \mathrm{~nm}$ and $625 \mathrm{~nm}$, respectively, under excitation at $365 \mathrm{~nm}$. In the present of $\mathrm{Hg}^{2+}$, the red fluorescence of Au NPs was quenched via metallophilic $\mathrm{Hg}^{2+}-\mathrm{Au}$ interactions while the green emission of the AIE particles almost remained unchanged, generating a ratiometric fluorescent signal. With higher affinity for $\mathrm{Hg}^{2+}$, melamine prevented the fluorescence quenching thus also could be detected with this sensor. Cell imaging assays demonstrated the effectiveness of this sensing strategy.

\section{2. $\mathrm{Cu} u^{2+}$}

Copper, as an important trace element, participates in the formation of some enzymes and proteins, such as amine oxidase and ceruloplasmin. However, high concentration of $\mathrm{Cu}^{2+}$ is toxic [69]. Derivates based on rhodamine are frequently used to detect $\mathrm{Cu}^{2+}$ via $\mathrm{Cu}^{2+}$-induced spirolactam ring-opening and hydrolysis processes to produce a turn-on response [70,71]. In the past years, AIE-based probes have also been designed for $\mathrm{Cu}^{2+}$ sensing and find applications in bioimaging [72-75].

Based on the coordination behavior of Schiff base towards $\mathrm{Cu}^{2+}$, Hou et al. synthesized a Schiff base derivative with a $\mathrm{Cu}^{2+}$ binding stoichiometry of 2:1 (Figure 6a) [72]. The resultant fluorescence enhancement at $455 \mathrm{~nm}$ was used as the signal for $\mathrm{Cu}^{2+}$ detection in HeLa cells. In addition to turn-on sensors, turn-off strategy was also employed for the development of $\mathrm{Cu}^{2+}$ probes by using Schiff base as the core structure. The condensation of salicylaldehyde and 2-hydroxy-1-naphthaldehyde presented two probes with Schiff base moiety (Figure 6b,c) [73]. These two probes were highly emissive at $534 \mathrm{~nm}$ and $530 \mathrm{~nm}$, respectively, by forming micron particles in water. The coordination with $\mathrm{Cu}^{2+}$ broke the planar conformation of the probes, therefore quenched the fluorescence. The turn-off signal was used to indicate the appearance of $\mathrm{Cu}^{2+}$ in KYSE510 cells. Another probe with pyrrole and coumarin units connected by Schiff base was also reported to detect $\mathrm{Cu}^{2+}$ by fluorescence quenching (Figure 6d) [74]. This probe displayed different emission in solvents with varied water/DMSO fractions. Fluorescence was quenched upon $\mathrm{Cu}^{2+}$ addition due to photoinduced electron transfer (PET) process and disassembling of the aggregates. The sensor was utilized for $\mathrm{Cu}^{2+}$ imaging in HeLa cells.

He et al. reported a dual-detection strategy for $\mathrm{Cu}^{2+}$ and ATP [75]. An amphiphile probe was designed by modifying oxyalkyl chains with 1,5,9-triazacyclododecane unit as $\mathrm{Cu}^{2+}$-targeting group. This probe assembled into micelles and emitted at $491 \mathrm{~nm}$ in aqueous solution. Upon $\mathrm{Cu}^{2+}$ chelation, fluorescence was quenched. Since ATP has higher affinity with $\mathrm{Cu}^{2+}$, fluorescence can be recovered. Such fluorescence recovery responded specifically to ATP with slightly interference from ADP. The on-off-on mode provided detection limits of $0.1 \mu \mathrm{M}$ for $\mathrm{Cu}^{2+}$ and $1.5 \mu \mathrm{M}$ for ATP. The quenching and recovering of blue emission located in cytoplasm of HeLa cells was successfully achieved. 
(a)<smiles>NNC(=O)N/N=C/c1ccc2ccc3cccc4ccc1c2c34</smiles>

(c)

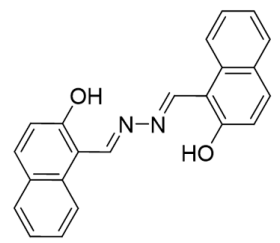

(b)

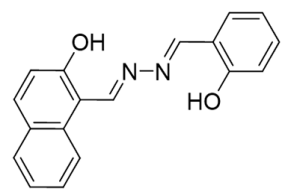

(d)

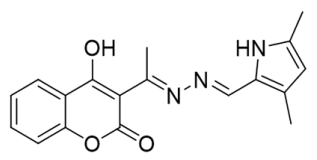

Figure 6. Molecular strucutres of chemosensor for $\mathrm{Cu}^{2+} \cdot \mathrm{Cu}^{2+}$ sensors reported in [72] (a), [73] (b), [73] (c), and [74] (d) (Reproduced with permission from [72-74]).

\section{3. $\mathrm{Zn}^{2+}$}

$\mathrm{Zn}^{2+}$ plays essential roles in the formation of zinc finger proteins, enzyme catalysis and signaling. The intracellular concentration of $\mathrm{Zn}^{2+}$ is around $200 \mu \mathrm{M}$ [76]. The imbalance of $\mathrm{Zn}^{2+}$ in human bodies is related to many diseases, including growth retardation, Alzheimer's disease and defects in immune systems [77,78]. AIE-active fluorescence probes have been developed for $\mathrm{Zn}^{2+}$ detection and sensing [79-83].

Jin and coworkers designed a Schiff-based compound, 2-(Trityliminomethyl)-quinolin-8-ol (HL), as ligand to coordinate with $\mathrm{Zn}^{2+}$ (Figure 7a) [79]. HL was non-emissive in $\mathrm{THF} / \mathrm{H}_{2} \mathrm{O}$ solution. However, the complex $\mathrm{ZnL}_{2}$ formed nanoscale J-aggregates through coordination bonds and $\pi-\pi$ interactions, thus showed obvious fluorescence. This turn-on mode was applied for detecting and imaging $\mathrm{Zn}^{2+}$ in SH-SY5Y cells. Recently, another Schiff base chemosensor Hbdhn with AIE properties was developed for imaging $\mathrm{Zn}^{2+}$ in living cells. (Figure 7b) [83]. In another example, Fan et al. designed an AIE probe to detect $\mathrm{Zn}^{2+}$ and single-stranded DNA (ssDNA) in different solvents [80]. In $\mathrm{H}_{2} \mathrm{O} / \mathrm{DMSO}\left(f_{w}=80 \%\right)$, the coexistence of $\mathrm{Zn}^{2+}$ with this probe caused fluorescence enhancement. However, in $\mathrm{H}_{2} \mathrm{O} / \mathrm{DMSO}\left(f_{w}=99 \%\right)$ a new metal complex $\mathrm{L}-\mathrm{Zn}^{2+}$ was produced which was weakly emissive. After addition of ssDNA, the metal coordination between ssDNA and $\mathrm{Zn}^{2+}$ enhanced the emission. This dual responsive turn-on approach was used to sense intracellular $\mathrm{Zn}^{2+}$ and ssDNA. Xiao et al. synthesized two AIE probes (SPF-1 and SPF-2) for $\mathrm{Zn}^{2+}$ sensing, by modifying spirobifluorene (Figure 7c,d) [81]. The detection limits were $0.3 \mu \mathrm{M}$ and $63 \mathrm{nM}$, respectively, based on AIE enhancement. SPF-1 was applied in the intracellular $\mathrm{Zn}^{2+}$ imaging of A549 cells with green fluorescence. Notably, SPF-2 was used for two-photon fluorescence imaging due to the donor- $\pi$-acceptor type molecule structure. In the cell imaging, yellow fluorescence was emitted from cells under excitation at $800 \mathrm{~nm}$.

(a)

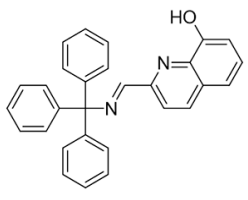

$\mathrm{HL}$

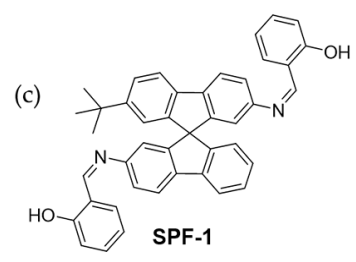

(b)

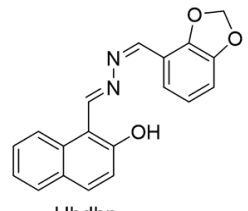

Hbdhn

(d)

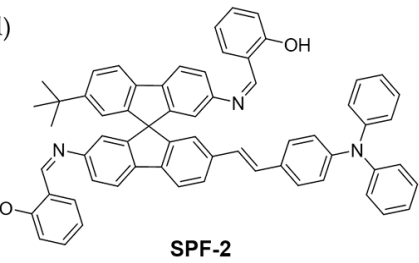

Figure 7. Molecular structures of chemosensors for $\mathrm{Zn}^{2+}$. (a) 2-(Trityliminomethyl)-quinolin-8-ol (HL) [79]. (b) Hbdhn [83]. (c) SPF-1 [81]. (d) SPF-2 [81] (Reproduced with permission from [79,81,83]). 
Integrating biomolecule into probes is an effective strategy for biosensing and bioimaging due to the good biocompatibility. Wang et al. designed a peptide-modified TPE probe to sense $\mathrm{Zn}^{2+}$ in a turn-on manner [82]. With a sequence of LHLHLRL, the peptide could selectively recognize $\mathrm{Zn}^{2+}$ via histidine residues by mimicking the $\mathrm{Zn}^{2+}$ binding site of carbonic anhydrase. Two glycine residues were introduced as spacer to connect the fluorophore and recognition group. The TPE unit provided fluorescence signal under aggregates. The detection of $\mathrm{Zn}^{2+}$ was realized in $80 \%$ aqueous buffered-ethanol solution (1 mM PBS, $\mathrm{pH} 7.0$ ), with a detection limit of $18.56 \mathrm{nM}$. This probe could image the intracellular $\mathrm{Zn}^{2+}$ in HeLa cells without internal addition of $\mathrm{Zn}^{2+}$. Furthermore, the permeability rate and intracellular concentration change of $\mathrm{Zn}^{2+}$ were also measured according to the emission of the probe.

In addition to organic probes, some nanoparticles and metal nanoclusters also show AIE behavior [84], and some of them have been used for $\mathrm{Zn}^{2+}$ sensing with the merits of simple preparation, broad excitation range and high photostability $[85,86]$. For instance, copper nanoclusters (Cu NCs) are frequently used for fluorescence analysis with AIE activity $[87,88]$. Zhao's group synthesized glutathione (GSH)-capped $\mathrm{Cu} N C$ s with AIE property for sensing $\mathrm{Zn}^{2+}$ [86]. Upon the addition of $\mathrm{Zn}^{2+}$ in buffered aqueous solution, $\mathrm{Cu}$ NCs bound $\mathrm{Zn}^{2+}$ via surface groups and electrostatic interaction. The crosslinking between clusters caused aggregation and emission enhancement due to the restriction of vibration, rotation, and torsion of $\mathrm{Cu}$ NCs. This light-up imaging of $\mathrm{Zn}^{2+}$ was also achieved in MGC-803 cells.

\section{4. $\mathrm{Fe}^{3+}$}

$\mathrm{Fe}^{3+}$ is one of the most common transition metals in the human body and participates in many biological activities, including oxygen carrying, electron transport, and enzyme catalysis. Nevertheless, the abnormality in $\mathrm{Fe}^{3+}$ has been revealed to correlate with many diseases, such as anemia, Parkinson's syndrome and cancer $[89,90]$. There have been many reports for $\mathrm{Fe}^{3+}$ detection with AIE probes [91-94].

Cyano group is usually used as the recognition group for the coordination of iron ions. Hence, combining cyano group and AIE fluorophore is an effective method to detecting $\mathrm{Fe}^{3+}$. Liu et al. designed an AIE probe containing cyano groups and triphenylamine unit to detect $\mathrm{Fe}^{3+}, \mathrm{CN}^{-}$, and $\mathrm{SO}_{3}{ }^{2-}$ [91]. In aqueous solution (1\% DMSO), fluorescence enhancement around $570 \mathrm{~nm}$ was observed due to the formation of nanoparticles from the probe. Upon the addition of $\mathrm{Fe}^{3+}$, the coordination from $\mathrm{Fe}^{3+}$ disturbed the hyperconjugation structure and caused fluorescence quenching. This turn-off mechanism could selectively discriminate $\mathrm{Fe}^{3+}$ from $\mathrm{Fe}^{2+}$. In imaging experiment, blue fluorescence of the probe was observed in the cytoplasm of HeLa cells. For cells treated with $\mathrm{Fe}^{3+}$, blue fluorescence disappeared in cells. Moreover, anion $\mathrm{CN}^{-}$and $\mathrm{SO}_{3}{ }^{2-}$ also quenched the fluorescence by affecting the charge density and breaking the hyperconjugation structure. Lee et al. reported an iron-selective turn-on sensor IQ44 which shows high affinity and sensitivity towards $\mathrm{Fe}^{3+}$. By localized to lysosomes, IQ44 can imaging cellular $\mathrm{Fe}^{3+}$ in lysosomes, and is promising for studying related biological processes (Figure 8a) [91].

(a)

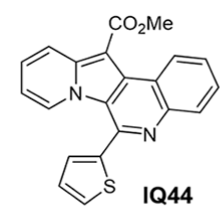

(b)

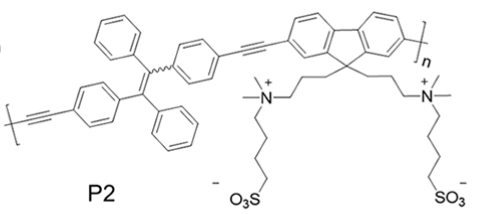

(c)

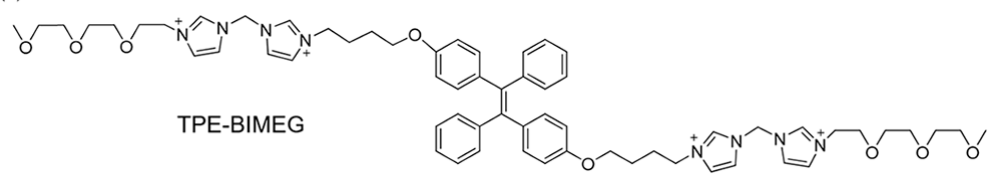

Figure 8. Molecular structures of chemosensors for $\mathrm{Fe}^{3+}$. (a) IQ44 [91]. (b) P2 [93]. (c) TPE-BIMEG [94] (Reproduced with permission from $[91,93,94])$. 
Fluorescence nanoparticles have been explored as sensors to sense $\mathrm{Fe}^{3+}[93,94]$. Wang et al. synthesized a conjugated polymer P2 for sensing $\mathrm{Fe}^{3+}$ (Figure 8b) [93]. This polymer containing TPE unit and zwitterionic unit. Then, DSPE-PEG 2000 was reprecipitated with P2, forming lipid-P2 NPs with spherical shape and an average diameter of $\sim 23 \mathrm{~nm}$. Lipid-P2 NPs displayed stable and strong emission at $500 \mathrm{~nm}$ in physiological conditions. The appearance of $\mathrm{Fe}^{3+}$ could quench the fluorescence. This turn-off response provided a detection limit for $\mathrm{Fe}^{3+}$ of $0.22 \mu \mathrm{M}$. Bioimaging of $\mathrm{Fe}^{3+}$ was achieved in A549 cells. Another example of fluorescent organic nanoparticles via self-assembly to sense and image $\mathrm{Fe}^{3+}$ was reported by $\mathrm{Li}$ et al. [94]. The fluorophore monomer TPE-BIMEG containing bis-imidazolium (BIM), oligo(ethyleneglycol) (EG), and TPE moieties (Figure 8c) showed good solubility in polar solvents. Due to the interaction between BIM and ATP, TPE-BIMEG could self-assemble into nanoparticles, which exhibited AIE enhancement around $470 \mathrm{~nm}$ in aqueous solution. Due to the excited state deactivation effect of $\mathrm{Fe}^{3+}$, the fluorescence of the nanoparticles could be quenched by $\mathrm{Fe}^{3+}$. The fluorescence quenching at a $\mathrm{Fe}^{3+}$ concentration as low as $0.1 \mathrm{nM}$ was observed, suggesting the high sensitivity of the method. During imaging of HeLa cells, strong fluorescence was emitted from the cytoplasm and cell membrane after incubation with TPE-BIMEG. In the presence of $\mathrm{Fe}^{3+}$, the measurement of fluorescence at different time points showed the fluorescence in HeLa cells could be completely quenched by $\mathrm{Fe}^{3+}$ within 30 min.

\subsection{Other Transition Metal Ions}

Besides the above-mentioned ions, other transition metal ions also draw research attentions.

Hahn et al. utilized TPE bridged tetraimidazolium salts, $\left[\mathrm{H}_{4} \mathrm{~L}-\mathrm{Et}\right]\left(\mathrm{PF}_{6}\right)_{4}$, and $\left[\mathrm{H}_{4} \mathrm{~L}-\mathrm{Bu}\right]\left(\mathrm{PF}_{6}\right)_{4}$, to chelate $\mathrm{Ag}^{+}$and $\mathrm{Au}^{+}$to form dinuclear tetracarbene complexes [94]. The restriction of the rotation of the phenyl groups caused sharp fluorescence enhancement at $500 \mathrm{~nm}$. Kim et al. designed a TPE probe to detect $\mathrm{Au}^{3+}$ based on AIEgen disaggregation effect [95]. The probe AuP-1 was prepared by decorating the TPE core with four propargyl groups (Figure 9a). In aqueous solution, the fluorescence of AuP-1 dramatically decreased within $1 \mathrm{~min}$ after the addition of $\mathrm{Au}^{3+}$. It was proposed that the interaction of $\mathrm{Au}^{3+}$ with alkynyl could convert aggregated AuP-1 to disaggregated form, therefore quenching the fluorescence. With low toxicity and high stability, this probe was applied for imaging $\mathrm{Au}^{3+}$ in RAW 264.7 cells. The inhibition of the green fluorescence from AuP-1 was used as the indicator of $\mathrm{Au}^{3+}$ inside cells.

a)

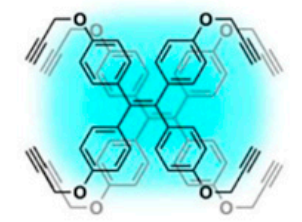

AuP-1

Aggregated-form

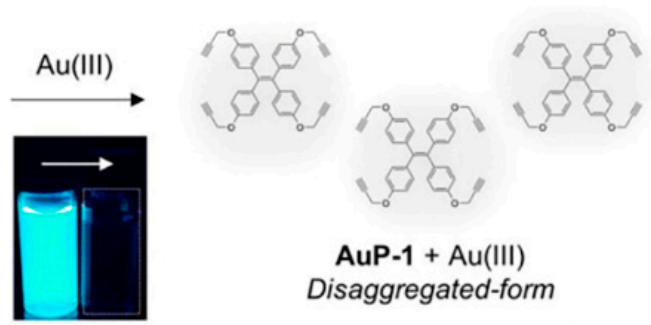

Highly Sensitive, Fast Responsive, Bio-imaging, Paper-strip

b)

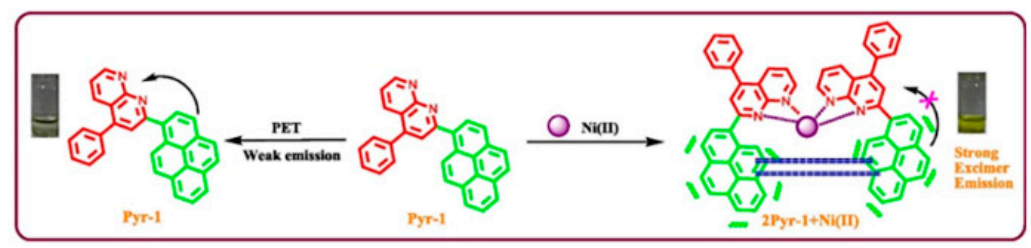

Figure 9. (a) Sensing of $\mathrm{Au}^{3+}$ with an AIE probe AuP-1 [96]. (b) Pyr-1 for $\mathrm{Ni}^{2+}$ sensing [97] (Reproduced with permission from [96,97]).

Pitchumani et al. reported a probe $\mathbf{P y r}-\mathbf{1}$ for $\mathrm{Ni}^{2+}$ detection which was synthesized from pyrene and 1,8-naphthyridine units (Figure 9b) [97]. Due to the PET process from pyrene to 1,8-naphthyridine, 
Pyr-1 was weakly emissive in dilute solution. Upon the addition of $\mathrm{Ni}^{2+}$, obvious fluorescence enhancement at $420 \mathrm{~nm}$ and red shift were observed. Mechanism investigation indicated that Pyr-1 and $\mathrm{Ni}^{2+}$ formed a square-planer complex with a stoichiometry of 2:1. The coordination operated between $\mathrm{Ni}^{2+}$ and $\mathrm{N}$ atoms in 1,8-naphthyridine. The emission enhancement was attributed to the inhibition of PET process and the formation of excimer. This probe showed high selectivity towards $\mathrm{Ni}^{2+}$ and a detection limit of $0.25 \mu \mathrm{M}$ in water. Successful application for $\mathrm{Ni}^{2+}$ imaging in HeLa cells was also demonstrated.

\section{Other Metal Ions}

Post-transition metals usually refer to aluminum (Al) gallium (Ga), indium (In), thallium ( $\mathrm{Tl}$ ), tin $(\mathrm{Sn})$, lead $(\mathrm{Pb})$, and bismuth $(\mathrm{Bi})$. Among these metal ions, current reported AIE probes mainly focus on $\mathrm{Al}^{3+}$ and $\mathrm{Pb}^{2+}$.

Zhao and coworkers designed a simple and effective probe TPE-COOH for $\mathrm{Al}^{3+}$ sensing [98]. In the presence of $\mathrm{Al}^{3+}$, the formation of coordination complex and nanoaggregates led to activatable emission at $470 \mathrm{~nm}$. The high selectivity was demonstrated by the discrimination of $\mathrm{Al}^{3+}$ from various metal ions. Quantitation analysis gave a detection limit of $21.6 \mathrm{nM}$ for $\mathrm{Al}^{3+}$. A time-course imaging of $\mathrm{Al}^{3+}$ was performed in HeLa cells to record the binding process of TPE-COOH to intracellular $\mathrm{Al}^{3+}$. Feng et al. introduced four carboxylate groups into one TPE core to sense $\mathrm{Al}^{3+}$ and $\mathrm{Pb}^{2+}[99]$. The probe TPE- $4 \mathrm{CO}_{2} \mathrm{Na}$ shows good solubility in pure aqueous solution. Both $\mathrm{Al}^{3+}$ and $\mathrm{Pb}^{2+}$ can coordinate with TPE- $4 \mathrm{CO}_{2} \mathrm{Na}$ to produce millimetre-sized aggregates. To examine the bio-applicability, Arabidopsis thaliana were chosen as the model. The acidic form of the probe TPE- $4 \mathrm{CO}_{2} \mathrm{H}$ exhibited better cell permeability and could sense the metal ions inside cells. Probes with pyrene structure were also reported to detect $\mathrm{Al}^{3+}, \mathrm{Fe}^{3+}$, and $\mathrm{Cr}^{3+}$ [100-102]. In one of such examples, monomeric pyrene PCS1 and dimeric PCS2 (Figure 10a) displayed AIE characteristic owing to the inhibition of PET/twisted intramolecular charge transfer (TICT) process in aggregates [102]. By using the turn-on response of PSC1 towards $\mathrm{Al}^{3+}, \mathrm{Fe}^{3+}$, and $\mathrm{Cr}^{3+}$, cell imaging experiments with RAW 264.7 cells were performed.

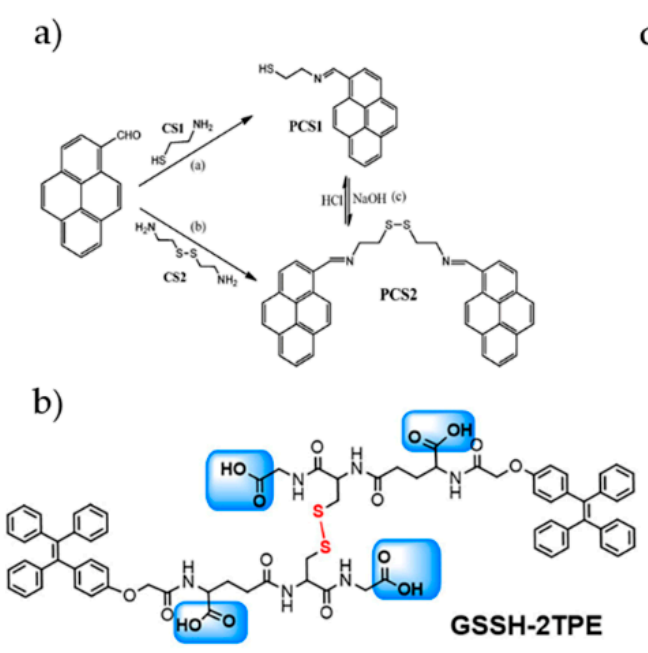

c)
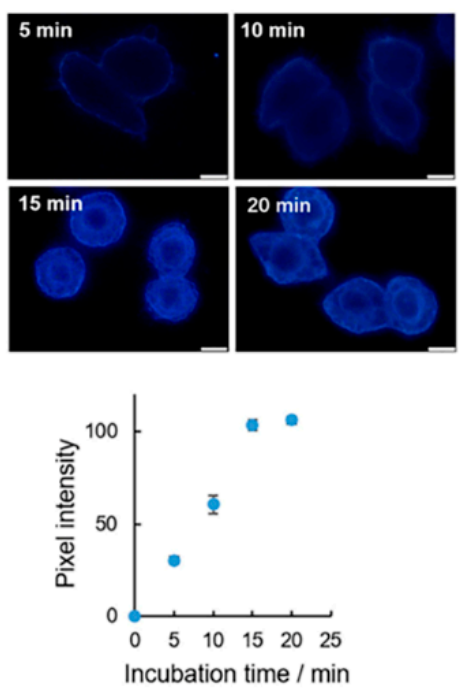

Figure 10. (a) Design and synthesis of PCS1 and PCS2 [102]. (b,c) Schematic illustration of GSSH-2TPE for $\mathrm{Pb}^{2+}$ sensing and imaging. (b) The design and synthesis of GSSH-2TPE. (c) Binding kinetics of GSSH-2TPE to $\mathrm{Pb}^{2+}$ in HeLa cells [103]. (Reproduced with permission from [102,103]).

Peptides with tailorable structures and rich coordination chemistry provide rich resource for designing recognition blocks. Huang and coworkers designed $\mathrm{Pb}^{2+}$-specific sensor by mimicking the structure of GSH [103] (Figure 10b). Lewis acid-base theory was employed to guide the modulation of the selectivity of the probe. With both hard Lewis base (the carboxyl group) and soft Lewis base (the thiol group), the leading structure GSH-TPE responded to several metal ions with turn-on 
fluorescence. After the oxidation of side groups, the probe GSSH-2TPE selectively recognized $\mathrm{Pb}^{2+}$ with high affinity due to the matched coordination configuration and cavity size. The complex further assembled into nanoparticles via the intermolecular noncovalent interactions, activating bright fluorescence. Endogenous biothiol species and metal ions such as GSH, cysteine, $\mathrm{Mg}^{2+}$, and $\mathrm{Ca}^{2+}$ hardly interfered the sensing performance. Cellular binding kinetics and biodistribution of $\mathrm{Pb}^{2+}$ were measured (Figure 10c). The higher intensity in cell membrane and cytoplasm suggested stronger retention and accumulation of $\mathrm{Pb}^{2+}$ in these compartments.

Uranium belonging to actinides group is a radioactive element and poses great threats to human health. Tang et al. developed a ratiometric fluorescence probe, 3-hydroxy-flavone salicylaldehyde azine (HFSA), for the detection and cell imaging of trace uranyl ion [104]. HFSA showed obvious emission enhancement in water/EtOH $\left(f_{w}=80 \%\right)$ at $534 \mathrm{~nm}$ due to AIE effect. In the presence of $\mathrm{UO}_{2}{ }^{2+}$, the emission at $534 \mathrm{~nm}$ remained unchanged while a new emission peak appeared at $457 \mathrm{~nm}$. This phenomenon was ascribed to the connection of $\mathrm{UO}_{2}{ }^{2+}$ with adjacent hydroxy groups in HFSA with a stoichiometric ratio of 1:2. The emission ratio $\left(I_{457} / I_{534}\right)$ was linearly dependent on the concentration of $\mathrm{UO}_{2}{ }^{2+}$ in the range of $0-20 \mathrm{ppb}$. This probe showed excellent selectivity for $\mathrm{UO}_{2}{ }^{2+}$ after $\mathrm{F}^{-}$addition and $\mathrm{pH}$ adjustment to reduce interference. During cell imaging, only yellow emission was observed in HFSA-treated HeLa cells. For cells loaded with $\mathrm{UO}_{2}{ }^{2+}$ and HFSA, both yellow and blue fluorescence was emitted, demonstrating the effectiveness of the probe for $\mathrm{UO}_{2}{ }^{2+}$ sensing.

\section{Conclusions}

Since the first introduction of fluorescence probes for metal ion sensing, great progress has been achieved both in fundamental mechanism and applications. The rapid development in instrumental tools and dyes not only allows the quantitative measurement of target molecules, but also permits in situ mapping the distribution of the analytes in a spatially resolved manner. In the past years, AIE-based sensors also contribute to the investigation of metal ions in living biosystem. Various fluorescent structures have been designed providing activatable signal and high sensitivity. Further decoration of these AIEgens with recognition moieties brings metal coordination or reaction abilities, thus high selectivity. The biological applications of the probes have been extended from simply qualitative detection to quantitative analysis and real-time tracing of metal ions in samples including living cells, microbe, plants, and fishes. The obtained information can benefit the insights into the roles of these metal ions.

There is broad space remaining for the future development of novel AIE-based sensors for metal ions. Considering the crucial biological functions of $\mathrm{Na}^{+}, \mathrm{K}^{+}, \mathrm{Ca}^{2+}$, and $\mathrm{Mg}^{2+}$, AIE sensors for them are relatively lack. Sensors selectively responding to these essential ions are desirable. Aiming at bioanalytical applications, attentions still should be paid on the water solubility and biocompability of the sensors. Shifting the emission to long wavelength range such as near infrared region is also appealing for bioimaging. This can benefit deep tissue penetrability thus enable monitoring of metal ions inside tissues. Due to the advantages of high penetrability and low phototoxicity, two-photon probes also attract increasing research interests. The development of two-photon AIEgens will benefit the investigation of metal ions in biosystems. Probes allowing tracking spatial distribution and kinetic process of cellular uptake of metal ions are also demanded. It is for sure that AIEgens for metal ions will continuously emerge and contribute to the field of bioanalysis.

Author Contributions: Conceptualization, Y.L. and Y.H.; writing-original draft preparation, Y.L. and Y.H.; All authors are involved in reviewing and editing of this paper.

Funding: This research was funded by the National Natural Science Foundation of China grants 21874141, 91853103, 21675161 and 21974143. Chinese Academy of Sciences and Youth Innovation Promotion Association CAS grant no.2015027.

Conflicts of Interest: The authors declare no conflict of interest. 


\section{References}

1. Carter, K.P.; Young, A.M.; Palmer, A.E. Fluorescent sensors for measuring metal ions in living systems. Chem. Rev. 2014, 114, 4564-4601. [CrossRef] [PubMed]

2. Bear, M.F.; Connors, B.; Paradiso, M. Neuroscience: Exploring the Brain, 3rd ed.; Lippincott Williams \& Wilkins: Baltimore, MD, USA, 2015.

3. Bischof, H.; Burgstaller, S.; Waldeck-Weiermair, M.; Rauter, T.; Schinagl, M.; Ramadani-Muja, J.; Graier, W.F.; Malli, R. Live-cell imaging of physiologically relevant metal ions using genetically encoded FRET-based probes. Cells 2019, 8, 492. [CrossRef] [PubMed]

4. Nelson, D.L.; Cox, M.M. Lehninger Principles of Biochemistry, 6th ed.; Worth Publishers: New York, NY, USA, 2012.

5. Weaver, R.F. Molecular Biology, 5th ed.; McGraw-Hill: New York, NY, USA, 2013.

6. Rauk, A. The chemistry of Alzheimer's disease. Chem. Soc. Rev. 2009, 38, 2698-2715. [CrossRef] [PubMed]

7. Qian, X.H.; Xu, Z.C. Fluorescence imaging of metal ions implicated in diseases. Chem. Soc. Rev. 2015, 44, 4487-4493. [CrossRef]

8. Ratte, H.T. Bioaccumulation and toxicity of silver compounds: A review. Environ. Toxicol. Chem. 1999, 18, 89-108. [CrossRef]

9. McLaughlin, M.J.; Parker, D.R.; Clarke, J.M. Metals and micronutrients-food safety issues. Field Crop. Res. 1999, 60, 143-163. [CrossRef]

10. Waisberg, M.; Joseph, P.; Hale, B.; Beyersmann, D. Molecular and cellular mechanisms of cadmium carcinogenesis. Toxicology 2003, 192, 95-117. [CrossRef]

11. de Silva, A.P.; Gunaratne, H.Q.N.; Gunnlaugsson, T.; Huxley, A.J.M.; McCoy, C.P.; Rademacher, J.T.; Rice, T.E. Signaling recognition events with fluorescent sensors and switches. Chem. Rev. 1997, 97, 1515-1566. [CrossRef]

12. Lee, M.H.; Kim, J.S.; Sessler, J.L. Small molecule-based ratiometric fluorescence probes for cations, anions, and biomolecules. Chem. Soc. Rev. 2015, 44, 4185-4191. [CrossRef]

13. Guo, Z.Q.; Park, S.; Yoon, J.; Shin, I. Recent progress in the development of near-infrared fluorescent probes for bioimaging applications. Chem. Soc. Rev. 2014, 43, 16-29. [CrossRef]

14. Zhou, J.; Ma, H.M. Design principles of spectroscopic probes for biological applications. Chem. Sci. 2016, 7, 6309-6315. [CrossRef] [PubMed]

15. Antina, E.V.; Bumagina, N.A.; V'yugin, A.I.; Solomonov, A.V. Fluorescent indicators of metal ions based on dipyrromethene platform. Dye. Pigment. 2017, 136, 368-381. [CrossRef]

16. Chan, J.; Dodani, S.C.; Chang, C.J. Reaction-based small-molecule fluorescent probes for chemoselective bioimaging. Nat. Chem. 2012, 12, 973-984. [CrossRef] [PubMed]

17. Jun, M.E.; Roy, B.; Ahn, K.H. “Turn-on" fluorescent sensing with "reactive” probes. Chem. Commun. 2011, 47, 7583-7601. [CrossRef] [PubMed]

18. Johnson, I.; Spence, M.T.Z. The Molecular Probes Handbook, 11th ed.; Invitrogen Corp.: Carlsbad, CA, USA, 2010.

19. Gao, M.; Tang, B.Z. Fluorescent sensors based on aggregation-induced emission: Recent advances and perspectives. ACS Sens. 2017, 2, 1382-1399. [CrossRef] [PubMed]

20. Luo, J.; Xie, Z.; Lam, J.W.Y.; Cheng, L.; Chen, H.; Qiu, C.; Kwok, H.S.; Zhan, X.; Liu, Y.; Zhu, D.; et al. Aggregation-induced emission of 1-methyl-1,2,3,4,5-pentaphenylsilole. Chem. Commun. 2001, 21, 1740-1741. [CrossRef]

21. Niu, G.L.; Zhang, R.Y.; Gu, Y.; Wang, J.G.; Ma, C.; Kwok, R.T.K.; Lam, J.W.Y.; Sung, H.H.Y.; Williams, I.D.; Wong, K.S.; et al. Highly photostable two-photo NIR AIEgens with tunable organelle specificity and deep tissue penetration. Biomaterials 2019, 208, 72-82. [CrossRef]

22. Mei, J.; Leung, N.L.C.; Kwok, R.T.K.; Lam, J.W.Y.; Tang, B.Z. Aggregation-induced emission: Together we shine, united we soar! Chem. Rev. 2015, 115, 11718-11940. [CrossRef]

23. Mei, J.; Hong, Y.; Lam, J.W.Y.; Qin, A.; Tang, Y.; Tang, B.Z. Aggregation-induced emission: The whole is more brilliant than the parts. Adv. Mater. 2014, 26, 5429-5479. [CrossRef]

24. Chen, J.W.; Law, C.C.W.; Lam, J.W.Y.; Dong, Y.P.; Lo, S.M.F.; Williams, I.D.; Zhu, D.B.; Tang, B.Z. Synthesis, light emission, nanoaggregation, and restricted intramolecular rotation of 1,1-substituted 2,3,4,5-tetraphenylsiloles. Chem. Mater. 2003, 15, 1535-1546. [CrossRef] 
25. Cai, Y.J.; Du, L.L.; Samedov, K.; Gu, X.G.; Qi, F.; Sung, H.H.Y.; Patrick, B.O.; Yan, Z.P.; Jiang, X.F.; Zhang, H.K.; et al. Deciphering the working mechanism of aggregation-induced emission of tetraphenylethylene derivatives by ultrafast spectroscopy. Chem. Sci. 2018, 9, 4662-4670. [CrossRef] [PubMed]

26. Zhuang, Y.; Huang, F.J.; Xu, Q.; Zhang, M.S.; Lou, X.D.; Xia, F. Facile, fast-responsive, and photostable imaging of telomerase activity in living cells with a fluorescence turn-on manner. Anal. Chem. 2016, 886, 3289-3294. [CrossRef] [PubMed]

27. Huang, Y.Y.; Hu, F.; Zhao, R.; Zhang, G.X.; Yang, H.; Zhang, D.Q. Tetraphenylethylene conjugated with a specific peptide as a fluorescence turn-on bioprobe for the highly specific detection and tracing of tumor markers in live cancer cells. Anal. Chem. 2014, 86, 7987-7995. [CrossRef] [PubMed]

28. Xu, X.J.; Huang, J.; Li, J.J.; Yan, J.W.; Qin, J.G.; Li, Z. A graphene oxide-based AIE biosensor with high selectivity toward bovine serum albumin. Chem. Commun. 2011, 47, 12385-12387. [CrossRef]

29. Shustova, N.B.; Ong, T.C.; Cozzolino, A.F.; Michaelis, V.K.; Griffin, R.G.; Dinca, M. Phenyl ring dynamics in a Tetraphenylethylene-bridged metal-organic framework: Implications for the mechanism of aggregation-induced emission. J. Am. Chem. Soc. 2012, 13436, 15061-15070. [CrossRef]

30. Shi, H.B.; Liu, J.Z.; Geng, J.L.; Tang, B.Z.; Liu, B. Specific detection of integrin $\alpha_{v} \beta_{3}$ by light-up bioprobe with aggregation-induced emission characteristics. J. Am. Chem. Soc. 2012, 13423, 9569-9572. [CrossRef]

31. Gu, X.G.; Kwok, R.T.K.; Lam, J.W.Y.; Tang, B.Z. AIEgens for biological process monitoring and disease theranostics. Biomaterials 2017, 146, 115-135. [CrossRef]

32. Hu, F.; Huang, Y.Y.; Zhang, G.X.; Zhao, R.; Yang, H.; Zhang, D.Q. Targeted bioimaging and photodynamic therapy of cancer cells with an activatable red fluorescent bioprobe. Anal. Chem. 2014, 86, 7987-7995. [CrossRef]

33. Xu, C.H.; Zou, H.; Zhao, Z.; Zhang, P.F.; Kwok, R.T.K.; Lam, J.W.Y.; Sung, H.H.Y.; Williams, I.D.; Tang, B.Z. A new strategy toward "simple" water-soluble AIE probes for hypoxia detection. Adv. Funct. Mater. 2019, 29, 1903278. [CrossRef]

34. Zhang, R.Y.; Sung, S.H.P.; Feng, G.X.; Zhang, C.J.; Kenry; Tang, B.Z.; Liu, B. Aggregation-induced emission probe for specific turn-on quantification of soluble transferrin receptor: An important disease marker for iron deficiency anemia and kidney diseases. Anal. Chem. 2018, 90, 1154-1160. [CrossRef]

35. Yin, J.; Hu, Y.; Yoon, J. Fluorescent probes and bioimaging: Alkali metals, alkaline earth metals and $\mathrm{pH}$. Chem. Soc. Rev. 2015, 44, 4619-4644. [CrossRef] [PubMed]

36. Lu, D.; He, L.; Wang, Y.; Xiong, M.; Hu, M.; Liang, H.; Huan, S.; Zhang, X.B.; Tan, W. Tetraphenylethene derivative modified DNA oligonucleotide for in situ potassium ion detection and imaging in living cells. Talanta 2017, 167, 550-556. [CrossRef] [PubMed]

37. Liu, M.; Yu, X.; Li, M.; Liao, N.X.; Bi, A.Y.; Jiang, Y.P.; Liu, S.; Gong, Z.C.; Zeng, W.B. Fluorescent probes for the detection of magnesium ions $\left(\mathrm{Mg}^{2+}\right)$ : From design to application. RSC Adv. 2018, 8, 12573-12587. [CrossRef]

38. Carroll, M.F.; Schade, D.S. A practical approach to hypercalcemia. Am. Fam. Physician. 2003, 67, $1959-1966$.

39. Zaheer, A.; Murshed, M.; De Grand, A.M.; Morgan, T.G.; Karsenty, G.; Frangioni, J.V. Optical imaging of hydroxyapatite in the calcified vasculature of transgenic animals. Arterioscler. Thromb. Vasc. Biol. 2006, 26, 1132-1136. [CrossRef]

40. Bian, Y.J.; Wang, L.Q.; Cao, F.X.; Tang, L.J. A simple fluorescence probe based on aggregation-induced emission (AIE) property for the detection of $\mathrm{Mg}^{2+}$ ions. J. Fluoresc. 2015, 26, 53-57. [CrossRef]

41. Ishiwari, F.; Hasebe, H.; Matsumura, S.; Hajjaj, F.; Horii-Hayashi, N.; Nishi, M.; Someya, T.; Fukushima, T. Bioinspired design of a polymer gel sensor for the realization of extracellular $\mathrm{Ca}^{2+}$ imaging. Sci. Rep. 2016, 6, 24275. [CrossRef]

42. Morishima, K.; Ishiwari, F.; Matsumura, S.; Fukushima, T.; Shibayama, M. Mesoscopic structural aspects of $\mathrm{Ca}^{2+}$-triggered polymer chain folding of a tetraphenylethene-appended poly(acrylic acid) in relation to its aggregation-induced emission behavior. Macromolecules 2017, 50, 5940-5945. [CrossRef]

43. Gao, M.; Li, Y.X.; Chen, X.H.; Li, S.W.; Ren, L.; Tang, B.Z. Aggregation-induced emission probe for light-up and in situ detection of calcium ions at high concentration. ACS Appl. Mater. Interfaces 2018, 10, 14410-14417. [CrossRef]

44. Zhang, J.D.; Yan, Z.; Wang, S.; She, M.Y.; Zhang, Z.; Cai, W.Z.; Liu, P.; Li, J.L. Water soluble chemosensor for $\mathrm{Ca}^{2+}$, based on aggregation-induced emission characteristics and its fluorescence imaging in living cells. Dye. Pigment. 2017, 150, 112-120. [CrossRef] 
45. Wang, P.; Jia, K.; Zhou, X.; Guan, X.; Wang, L.; Tian, Y.; Wu, C.; Liu, X. Ca ${ }^{2+}$ induced crosslinking of AIE-active polyarylene ether nitrile into fluorescent polymeric nanoparticles for cellular bioimaging. Macromol. Rapid Commun. 2017, 38, 1700360. [CrossRef] [PubMed]

46. Chen, G.L.; Zhou, Z.C.; Feng, H.; Zhang, C.Y.; Wang, Y.F.; Qian, Z.S.; Pan, J.W. An Aggregation-induced phosphorescence probe for calcium ion-specific detection and live-cell imaging in Arabidopsis Thaliana. Chem. Commun. 2019, 55, 4841-4844. [CrossRef] [PubMed]

47. Rurack, K. Flipping the light switch 'ON'-the design of sensor molecules that show cation-induced fluorescence enhancement with heavy and transition metal ions. Spectroc. Acta Pt. A-Molec. Biomolec. Spectr. 2001, 57, 2161-2195. [CrossRef]

48. Aron, A.T.; Ramos-Torres, K.M.; Cotruvo, J.A.; Chang, C.J. Recognition- and reactivity-based fluorescent probes for studying transition metal signaling in living systems. Acc. Chem. Res. 2015, 48, 2434-2442. [CrossRef] [PubMed]

49. Stein, E.D.; Cohen, Y.; Winer, A.M. Environmental distribution and transformation of mercury compounds. Crit. Rev. Environ. Sci. Technol. 1996, 26, 1-43. [CrossRef]

50. Li, W.C.; Tse, H.F. Health risk and significance of mercury in the environment. Environ. Sci. Pollut. Res. 2015, 22, 192-201. [CrossRef]

51. Wang, K.; Li, J.J.; Ji, S.M.; Li, L.J.; Qiu, Z.P.; Pan, C.Q.; Zhang, J.Y.; Huo, Y.P. Fluorescence probes based on AIE luminogen: Application for sensing $\mathrm{Hg}^{2+}$ in aqueous media and cellular imaging. New J. Chem. 2018, 42, 13836-13846. [CrossRef]

52. Zhang, G.B.; Ding, A.X.; Zhang, Y.; Yang, L.M.; Kong, L.; Zhang, X.J.; Tao, X.T.; Tian, Y.P.; Yang, J.X. Schiff base modified $\alpha$-cyanostilbene derivative with aggregation-induced emission enhancement characteristics for $\mathrm{Hg}^{2+}$ detection. Sens. Actuator B-Chem. 2014, 202, 209-216. [CrossRef]

53. Zhang, G.B.; Zhang, X.J.; Zhang, Y.; Wang, H.; Kong, L.; Tian, Y.P.; Tao, X.T.; Hong, B.; Yang, J.X. Design of turn-on fluorescent probe for effective detection of $\mathrm{Hg}^{2+}$ by combination of AIEE-active fluorophore and binding site. Sens. Actuator B-Chem. 2015, 221, 730-739. [CrossRef]

54. Fang, W.Y.; Zhang, G.B.; Chen, J.; Kong, L.; Yang, L.M.; Bi, H.; Yang, J.X. An AIE active probe for specific sensing of $\mathrm{Hg}^{2+}$ based on linear conjugated bis-Schiff base. Sens. Actuator B-Chem. 2016, 229, 338-346. [CrossRef]

55. Gui, S.L.; Huang, Y.Y.; Hu, F.; Jin, Y.L.; Zhang, G.X.; Zhang, D.Q.; Zhao, R. Bioinspired peptide for imaging $\mathrm{Hg}^{2+}$ distribution in living cells and Zebrafish based on coordination-mediated supramolecular assembling. Anal. Chem. 2018, 90, 9708-9715. [CrossRef] [PubMed]

56. Yuan, B.; Wang, D.X.; Zhu, L.N.; Lan, Y.L.; Cheng, M.; Zhang, L.M.; Chu, J.Q.; Li, X.Z.; Kong, D.M. Dinuclear $\mathrm{HgII}$ tetracarbene complex-triggered aggregation-induced emission for rapid and selective sensing of $\mathrm{Hg}^{2+}$ and organomercury species. Chem. Sci. 2019, 10, 4220-4226. [CrossRef] [PubMed]

57. Huang, L.T.; Li, S.W.; Ling, X.; Zhang, J.; Qin, A.J.; Zhuang, J.; Gao, M.; Tang, B.Z. Dual detection of bioaccumulated $\mathrm{Hg}^{2+}$ based on luminescent bacteria and aggregation-induced emission. Chem. Commun. 2019, 55, 7458-7461. [CrossRef] [PubMed]

58. Wu, Y.Q.; Wen, X.Y.; Fan, Z.F. An AIE active pyrene based fluorescent probe for selective sensing $\mathrm{Hg}^{2+}$ and imaging in live cells. Spectroc. Acta Pt. A-Molec. Biomolec. Spectr. 2019, 223, 117315. [CrossRef] [PubMed]

59. Bahta, M.; Ahmed, N. Naphthalimide-amino acid conjugates chemosensors for $\mathrm{Hg}^{2+}$ detection: Based on chelation mediated emission enhancement in aqueous solution. J. Photochem. Photobiol. A-Chem. 2019, 378, 85-93. [CrossRef]

60. Gabr, M.T.; Pigge, F.C. A turn-on AIE active fluorescent sensor for $\mathrm{Hg}^{2+}$ by combination of 1,1-bis(2-pyridyl)ethylene and thiophene/bithiophene fragments. Mater. Chem. Front. 2017, 1, 1654-1661. [CrossRef]

61. Jiang, Y.; Duan, Q.Y.; Zheng, G.S.; Yang, L.; Zhang, J.; Wang, Y.F.; Zhang, H.T.; He, J.; Sun, H.Y.; Ho, D. An ultra-sensitive and ratiometric fluorescent probe based on the DTBET process for $\mathrm{Hg}^{2+}$ detection and imaging applications. Analyst 2019, 144, 1353-1360. [CrossRef]

62. Mukherjee, S.; Thilagar, P. Molecular flexibility tuned emission in "V" shaped naphthalimides: $\mathrm{Hg}(\mathrm{II})$ detection and aggregation induced emission enhancement (AIEE). Chem. Commun. 2013, 49, 7292-7294. [CrossRef] 
63. Wang, A.Z.; Yang, Y.X.; Yu, F.F.; Xue, L.W.; Hu, B.W.; Fan, W.P.; Dong, Y.J. A highly selective and sensitive fluorescent probe for quantitative detection of $\mathrm{Hg}^{2+}$ based on aggregation-induced emission features. Talanta 2015, 132, 864-870. [CrossRef]

64. Chatterjee, A.; Banerjee, M.; Khandare, D.G.; Gawas, R.U.; Mascarenhas, S.C.; Ganguly, A.; Gupta, R.; Joshi, H. Aggregation-induced emission-based chemodosimeter approach for selective sensing and imaging of $\mathrm{Hg}$ (II) and methylmercury species. Anal. Chem. 2017, 89, 12698-12704. [CrossRef]

65. Gao, T.; Huang, X.Y.; Huang, S.; Dong, J.; Yuan, K.; Feng, X.P.; Liu, T.T.; Yu, K.Q.; Zeng, W.B. Sensitive water-soluble fluorescent probe based on umpolung and aggregation-induced emission strategies for selective detection of $\mathrm{Hg}^{2+}$ in living cells and Zebrafish. J. Agric. Food Chem. 2019, 67, 2377-2383. [CrossRef] [PubMed]

66. Huang, S.; Gao, T.; Bi, A.Y.; Cao, X.Z.; Feng, B.; Liu, M.; Du, T.; Feng, X.P.; Zeng, W.B. Revealing aggregation-induced emission effect of imidazolium derivatives and application for detection of $\mathrm{Hg}^{2+}$. Dye Pigment. 2020, 172, 107830. [CrossRef]

67. Chen, S.; Wang, W.J.; Yan, M.M.; Tu, Q.; Chen, S.W.; Li, T.B.; Yuan, M.S.; Wang, J.Y. 2-Hydroxy benzothiazole modified rhodol: Aggregation-induced emission and dual-channel fluorescence sensing of $\mathrm{Hg}^{2+}$ and $\mathrm{Ag}^{+}$ ions. Sens. Actuator B-Chem. 2018, 255, 2086-2094. [CrossRef]

68. Niu, C.X.; Liu, Q.L.; Shang, Z.H.; Zhao, L.; Ouyang, J. Dual-emission fluorescent sensor based on AIE organic nanoparticles and Au nanoclusters for the detection of mercury and melamine. Nanoscale 2015, 7, 8457-8465. [CrossRef] [PubMed]

69. Kepp, K.P.; Squitti, R. Copper imbalance in Alzheimer's disease: Convergence of the chemistry and the clinic. Coord. Chem. Rev. 2019, 397, 168-187. [CrossRef]

70. Dujols, V.; Ford, F.; Czarnik, A.W. A long-wavelength fluorescent chemodosimeter selective for $\mathrm{Cu}(\mathrm{II})$ ion in water. J. Am. Chem. Soc. 1997, 119, 7386-7387. [CrossRef]

71. Xu, J.; Hou, Y.; Ma, Q.; Wu, X.; Feng, S.; Zhang, J.; Shen, Y. A highly selective fluorescent probe for $\mathrm{Cu}^{2+}$ based on rhodamine B derivative. Spectroc. Acta Pt. A-Molec. Biomolec. Spectr. 2014, 124, 416-422. [CrossRef]

72. Wu, W.N.; Mao, P.D.; Wang, Y.; Mao, X.J.; Xu, Z.Q.; Xu, Z.H.; Zhao, X.L.; Fan, Y.C.; Hou, X.F. AEE active Schiff base-bearing pyrene unit and further $\mathrm{Cu}^{2+}$-induced self-assembly process. Sens. Actuator B-Chem. 2018, 258, 393-401. [CrossRef]

73. Singh, A.; Singh, R.; Shellaiah, M.; Prakash, E.C.; Chang, H.C.; Raghunath, P.; Lin, M.C.; Lin, H.C.; Liu, B.; Zhou, H.L.; et al. Aggregation-induced emission activity and further $\mathrm{Cu}^{2+}$-induced self-assembly process of two Schiff compounds. Sens. Actuator B-Chem. 2017, 246, 554-562.

74. Wang, Y.; Wu, H.; Wu, W.N.; Li, S.J.; Xu, Z.H.; Xu, Z.Q.; Fan, Y.C.; Zhao, X.L.; Liu, B.Z. An AIRE active Schiff base bearing coumarin and pyrrole unit: $\mathrm{Cu}^{2+}$ detection in either solution or aggregation states. Sens. Actuator B-Chem. 2018, 260, 106-115. [CrossRef]

75. Ding, A.X.; Shi, Y.D.; Zhang, K.X.; Sun, W.; Tan, Z.L.; Lu, Z.L.; He, L. Self-assembled aggregation-induced emission micelle (AIE micelle) as interfacial fluorescence probe for sequential recognition of $\mathrm{Cu}^{2+}$ and ATP in water. Sens. Actuator B-Chem. 2018, 255, 440-447. [CrossRef]

76. Maret, W. Crosstalk of the group IIa and IIb metals calcium and zinc in cellular signaling. Proc. Natl. Acad. Sci. USA 2001, 98, 12325-12327. [CrossRef] [PubMed]

77. Frederickson, C.J.; Koh, J.Y.; Bush, A.I. The neurobiology of zinc in health and disease. Nat. Rev. Neurosci. 2005, 6, 449-462. [CrossRef] [PubMed]

78. Arena, G.; Rizzarelli, E. $\mathrm{Zn}^{2+}$ interaction with Amyloid-B: Affinity and speciation. Molecules 2019, $24,2796$. [CrossRef] [PubMed]

79. Wang, D.; Li, S.M.; Zheng, J.Q.; Kong, D.Y.; Zheng, X.J.; Fang, D.C.; Jin, L.P. Coordination-directed stacking and aggregation-induced emission enhancement of the $\mathrm{Zn}(\mathrm{II})$ Schiff base complex. Inorg. Chem. 2017, 56, 984-990. [CrossRef] [PubMed]

80. Wen, X.Y.; Wang, Q.; Fan, Z.F. An active fluorescent probe based on aggregation-induced emission for intracellular bioimaging of $\mathrm{Zn}^{2+}$ and tracking of interactions with single-stranded DNA. Anal. Chim. Acta 2018, 1013, 79-86. [CrossRef] [PubMed]

81. Wan, J.Y.; Zhang, W.; Guo, H.D.; Liang, J.J.; Huang, D.Y.; Xiao, H.B. Two spirobifluorene-based fluorescent probes with aggregation-induced emission properties: Synthesis and application in the detection of $\mathrm{Zn}^{2+}$ and cell imaging. J. Mater. Chem. C 2019, 7, 2240-2249. [CrossRef] 
82. He, X.X.; Wang, X.M.; Zhang, L.; Fang, G.Z.; Liu, J.F.; Wang, S. Sensing and intracellular imaging of Zn ${ }^{2+}$ based on affinity peptide using an aggregation induced emission fluorescence "switch-on" probe. Sens. Actuator B-Chem. 2018, 271, 289-299. [CrossRef]

83. Naskar, B.; Dhara, A.; Maiti, D.K.; Kukulka, M.; Mitoraj, M.P.; Srebro-Hooper, M.; Prodhan, C.; Chaudhuri, K.; Goswami, S. Aggregation-induced emission-based sensing platform for selective detection of $\mathrm{Zn}^{2+}$ : Experimental and theoretical investigations. Chem. Phys. Chem. 2019, 20, 1630-1639. [CrossRef]

84. Wang, J.X.; Lin, X.F.; Shu, T.; Su, L.; Liang, F.; Zhang, X.J. Self-assembly of metal nanoclusters for aggregation-induced emission. Int. J. Mol. Sci. 2019, 20, 1891. [CrossRef]

85. Guo, Y.M.; Cao, F.P.; Lei, X.L.; Mang, L.H.; Cheng, S.J.; Song, J.T. Fluorescent copper nanoparticles: Recent advances in synthesis and applications for sensing metal ions. Nanoscale 2016, 8, 4852-4863. [CrossRef] [PubMed]

86. Lin, L.Y.; Hu, Y.F.; Zhang, L.L.; Huang, Y.; Zhao, S.L. Photoluminescence light-up detection of zinc ion and imaging in living cells based on the aggregation induced emission enhancement of glutathione-capped copper nanoclusters. Biosens. Bioelectron. 2017, 94, 523-529. [CrossRef] [PubMed]

87. Jia, X.F.; Li, J.; Wang, E.K. Cu nanoclusters with aggregation induced emission enhancement. Small 2013, 9, 3873-3879. [CrossRef] [PubMed]

88. Li, D.; Chen, Z.H.; Wan, Z.H.; Yang, T.Z.; Wang, H.; Mei, X.F. One-pot development of water-soluble copper nanoclusters with red emission and aggregation induced fluorescence enhancement. RSC Adv. 2016, 6, 34090-34095. [CrossRef]

89. Rouault, T.A. The role of iron regulatory proteins in mammalian iron homeostasis and disease. Nat. Chem. Biol. 2006, 2, 406-414. [CrossRef]

90. Gozzelin, R.; Arosio, P. Iron homeostasis in health and disease. Int. J. Mol. Sci. 2016, 17, 130. [CrossRef]

91. Lim, B.; Baek, B.; Jang, K.; Lee, N.K.; Lee, J.H.; Lee, Y.; Kim, J.; Kang, S.W.; Park, J.; Kim, S.; et al. Novel turn-on fluorescent biosensors for selective detection of cellular $\mathrm{Fe}^{3+}$ in lysosomes: Thiophene as a selectivity-tuning handle for $\mathrm{Fe}^{3+}$ sensors. Dye. Pigment. 2019, 169, 51-59. [CrossRef]

92. Yang, X.D.; Chen, X.L.; Lu, X.D.; Yan, C.G.; Xu, Y.K.; Hang, X.D.; Qu, J.Q.; Liu, R.Y. A highly selective and sensitive fluorescent chemosensor for detection of $\mathrm{CN}^{-}, \mathrm{SO}_{3}{ }^{2-}$ and $\mathrm{Fe}^{3+}$ based on aggregation-induced emission. J. Mater. Chem. C 2016, 4, 383-390. [CrossRef]

93. Yang, D.L.; Li, F.; Luo, Z.M.; Bao, B.Q.; Hu, Y.L.; Weng, L.X.; Cheng, Y.X.; Wang, L.H. Conjugated polymer nanoparticles with aggregation induced emission characteristics for intracellular $\mathrm{Fe}^{3+}$ sensing. J. Polym. Sci. Part A Polym. Chem. 2016, 54, 1686-1693. [CrossRef]

94. Yang, Y.; Wang, X.Y.; Cui, Q.L.; Cao, Q.; Li, L.D. Self-assembly of fluorescent organic nanoparticles for iron(III) sensing and cellular imaging. ACS Appl. Mater. Interfaces 2016, 8, 7440-7448. [CrossRef]

95. Sinha, N.; Stegemann, L.; Tan, T.T.Y.; Doltsinis, N.L.; Strassert, C.A.; Hahn, F.E. Turn-on fluorescence in Tetra-NHC ligands by rigidification through metal complexation: An alternative to aggregation-induced emission. Angew. Chem. Int. Ed. 2017, 56, 2785-2789. [CrossRef] [PubMed]

96. Kim, N.H.; Won, M.; Kim, J.S.; Huh, Y.; Kim, D. A highly sensitive and fast responsive fluorescent probe for detection of Gold(III) ions based on the AIEgen disaggregation. Dye Pigment 2019, 160, 647-653. [CrossRef]

97. Khan, R.I.; Ramu, A.; Pitchumani, K. Design and one-pot synthesis of a novel pyrene based fluorescent sensor for selective "turn on", naked eye detection of $\mathrm{Ni}^{2+}$ ions, and live cell imaging. Sens. Actuator B-Chem. 2018, 266, 429-437. [CrossRef]

98. Gui, S.L.; Huang, Y.Y.; Hu, F.; Jin, Y.I.; Zhang, G.X.; Yan, L.S.; Zhang, D.Q.; Zhao, R. Fluorescence turn-on chemosensor for highly selective and sensitive detection and bioimaging of $\mathrm{Al}^{3+}$ in living cells based on ion-induced aggregation. Anal. Chem. 2015, 87, 1470-1474. [CrossRef] [PubMed]

99. Xu, P.F.; Bao, Z.Y.; Yu, C.Y.; Qiu, Q.Q.; Wei, M.R.; Xi, W.B.; Qian, Z.S.; Feng, H. A water-soluble molecular probe with aggregation-induced emission for discriminative detection of $\mathrm{Al}^{3+}$ and $\mathrm{Pb}^{2+}$ and imaging in seedling root of Arabidopsis. Spectroc. Acta Pt. A-Molec. Biomolec. Spectr. 2019, 223, 117335. [CrossRef] [PubMed]

100. Singh, A.; Singh, R.; Shellaiah, M.; Prakash, E.C.; Chang, H.C.; Raghunath, P.; Lin, M.C.; Lin, H.C. A new pyrene-based aggregation induced ratiometric emission probe for selective detections of trivalent metal ions and its living cell application. Sens. Actuator B-Chem. 2015, 207, 338-345. [CrossRef] 
101. Simon, T.; Shellaiah, M.; Srinivasadesikan, V.; Lin, C.C.; Ko, F.H.; Sun, K.W.; Lin, M.C. A simple pyrene based AIEE active schiff base probe for selective naked eye and fluorescence off-on detection of trivalent cations with live cell application. Sens. Actuator B-Chem. 2016, 231, 18-29. [CrossRef]

102. Shellaiah, M.; Simon, T.; Srinivasadesikan, V.; Lin, C.M.; Sun, K.W.; Ko, F.H.; Lin, M.C.; Lin, H.C. Novel pyrene containing monomeric and dimeric supramolecular AIEE active nano-probes utilized in selective "off-on" trivalent metal and highly acidic $\mathrm{pH}$ sensing with live cell applications. J. Mater. Chem. C 2016, 4, 2056-2071. [CrossRef]

103. Gui, S.L.; Huang, Y.Y.; Zhu, Y.Y.; Jin, Y.L.; Zhao, R. Biomimetic sensing system for tracing $\mathrm{Pb}^{2+}$ distribution in living cells based on the metal-peptide supramolecular assembly. ACS Appl. Mater. Interfaces 2019, 11, 5804-5811. [CrossRef]

104. Chen, X.T.; Peng, L.; Feng, M.L.; Xiang, Y.; Tong, A.J.; He, L.F.; Liu, B.; Tang, Y.P. An aggregation induced emission enhancement-based ratiometric fluorescent sensor for detecting trace uranyl ion $\left(\mathrm{UO}_{2}{ }^{2+}\right)$ and the application in living cells imaging. J. Lumines. 2017, 186, 301-306. [CrossRef]

Sample Availability: Samples of the compounds are not available from the authors.

(C) 2019 by the authors. Licensee MDPI, Basel, Switzerland. This article is an open access article distributed under the terms and conditions of the Creative Commons Attribution (CC BY) license (http://creativecommons.org/licenses/by/4.0/). 